\title{
Antibiogram and plasmid profiling of resistance bacteria isolated from the blood of Hepatitis CVirus positive individuals
}

\begin{abstract}
In this investigation, the types of bacteria present in the blood of Hepatitis $\mathrm{C}$ Virus (HCV) positive individuals attending State General Hospital, Akure, Ondo State, their antibiogram and plasmid profiling. The blood was collected and subjected to standard microbiological techniques to isolate and identify the types of bacteria present. These were subjected to antibiotics disk to determine the antibiogram profile and multiple antibiotics resistance (MAR) pattern was determined. Plasmid profiling and curing was done to determine the genetic basis for resistance of the bacterial isolates. The bacteria species identified are Staphylococcus aureus, Klebsiella pneumoniae, Pseudomonas aeruginosa, Escherichia coli, Streptococcus pneumoniae, Proteus mirabilis and Salmonella species and most of the isolates showed multiple antibiotics resistance (MAR). The antibiogram profile of isolates revealed Ciprofloxacin as the most effective antibiotic against most isolated bacterial species while they are resistance to most of other antibiotics especially Amoxycillin, Cotrimozazole and Ceftriazone. The plasmid analysis shows that all multiple resistant bacterial isolates harbor one or more plasmids with different molecular weights and plasmid curing converts all the isolates (MAR) which were initially resistant to the conventional antibiotics to susceptible form thereby indicating that, the resistance was plasmid mediated.
\end{abstract}

Keywords: antibiogram, plasmid, antibiotics, resistance, susceptibility
Volume 7 Issue 3 - 2019

\author{
Akande EB, Abodunrin TF, Oladejo BO and \\ Oladunmoye MK \\ Department of Microbiology, Federal University of Technology, \\ Nigeria
}

Correspondence: Akande EB, Department of Microbiology, Federal University of Technology, Akure, Ondo State, Nigeria, Tel +2348039413648, Email akandeemmanuelb@gmail.com

Received: May 30, 2019 | Published: June II, 2019

\section{Introduction}

Hepatitis $\mathrm{C}$ is an inflammatory process in the liver which is characterized by diffuse hepatocellular necrosis. In addition to viral, bacterial and fungal agents, hepatitis can also be caused by drugs, chemicals and toxins. ${ }^{1}$ Hepatitis $\mathrm{C}$ is an infectious disease caused by the hepatitis $\mathrm{C}$ virus (HCV) that primarily affects the liver. ${ }^{2}$ During the initial infection people often show mild or no symptoms. Occasionally a fever, dark urine, abdominal pain, and yellow tinged skin occur. The virus persists in the liver in about $75 \%$ to $85 \%$ of those initially infected. Early chronic infection typically has no symptoms. Over many years however, it often leads to liver disease and occasionally cirrhosis. ${ }^{3}$ In some cases, those with cirrhosis will develop complications such as liver failure, liver cancer, or esophageal and gastric varices. ${ }^{2}$ $\mathrm{HCV}$ is spread primarily by blood-to-blood contact associated with intravenous drug use, poorly sterilized medical equipment, needle stick injuries in healthcare, and transfusions. ${ }^{3,4}$ With blood screening for $\mathrm{HCV}$, the risk from a transfusion is less than one per two million. ${ }^{3}$ It can also be spread from an infected mother to her baby during birth. ${ }^{3}$ It is not spread by superficial contact. ${ }^{5}$ It is one of five known hepatitis viruses: A, B, C, D, and E. ${ }^{6}$ Diagnosis is by blood test to check for either antibodies to the virus or its RNA. Test is recommended for all people who are at risk. ${ }^{3}$

The genome of HCV is highly mutable. Because HCV is an RNA virus and lacks efficient proofreading ability as it replicates, virions infecting humans undergo evolution with time, giving rise to the notion that $\mathrm{HCV}$ persists as a collection of virus quasi-species. By constant mutation, HCV may be able to escape host immunologic detection and elimination. ${ }^{7-9} \mathrm{HCV}$ undergoes rapid mutation in a hyper variable region of the genome coding for the envelope proteins and escapes immune surveillance of the host. As a consequence, most $\mathrm{HCV}$ infected people develop chronic infection. HCV also knocks out the host's Innate Immunity. ${ }^{10}$ Scar tissue in the liver restricts the flow of blood and leads to portal hypertension resulting in complications such as ascites, spontaneous bacterial peritonitis, varices and other potentially life-threatening complications. Spontaneous bacterial peritonitis is a condition caused when the body's natural bacteria enters the ascites fluid causing severe infection. This study therefore is to screen the blood of HCV positive individuals in the studied community for the types of bacterial pathogens present, their resistance basis and to know the antibiogram profile of these microorganisms.

\section{Materials and methods}

The study was carried out at State General Hospital, Akure and Don Bosco Diagnostic Medical Center, Akure, where the participants were recruited from the different departments. The blood samples were collected after approval by the ethical review committee of the healthcare institution. The sampling and isolation processes with suitable bacteriological media were commenced in October, 2016.

\section{Isolation and identification of associated bacteria}

A total of One hundred and twenty one (121) confirmed HCV blood samples were used for the research. In the Department of Microbiology laboratory, Federal University of Technology, Akure, Nigeria. About two milliliters $(2 \mathrm{ml})$ of the $\mathrm{HCV}$ positive sample was introduced into $5 \mathrm{ml}$ Brain-Heart infusion broth and were incubated at $37^{\circ} \mathrm{C}$ for $24 \mathrm{~h}$ before culturing on suitable agar plates (Nutrient agar, MacConkey agar, Chocolate agar and Blood agar plates) for bacterial 
growth. ${ }^{11}$ The bacterial isolates from each plate were sub cultured for pure colonies and incubated at $37^{\circ} \mathrm{C}$ for $18-24 \mathrm{~h}$. Identification of bacterial pathogens was carried out by biochemical tests. Gram staining was performed to differentiate the Gram positive and Gram negative bacteria. ${ }^{12}$

\section{Biochemical tests}

For identification of the bacterial isolates, biochemical tests were performed. These include Gram-staining, catalase production, motility test, coagulase, oxidase test, indole production and sugar fermentation using the methods of Olutiola et al., ${ }^{13}$ and Cheesbrough. ${ }^{14}$

\section{Gram staining}

A small drop of distilled water was placed on a clean grease free slide and with the help of an inoculating needle; the isolate was picked from the surface of agar plate and gently emulsified in the water dropped, and spread to make a thin smear. The smear was air dried and passed through a Bunsen flame to fix. It was then flooded with crystal violet for about 30 seconds and rinsed off with water. Lugol's iodine solution was then applied for 30 seconds and washed off. Ninety five (95\%) ethyl alcohol was applied for 30 seconds. It was again washed with water and safranin was added and left for 30 seconds. The safranin was then washed off and the smear dried in air The slide was examined under oil immersion microscope. ${ }^{14}$

\section{Catalase production}

A drop of sterile water was placed on a clean glass slide; the bacterial isolate was picked with a flamed wire loop and emulsified on the glass slide. Several drops of 3\% hydrogen peroxide were added and were observed for the presence of bubbles. An effervescence bubble formation was observed which indicated a positive catalase test. ${ }^{14}$

\section{Triple sugar iron (TSI) test}

The Triple Sugar Iron (TSI) test is a microbiological test roughly named for its ability to test a microorganism's ability to ferment sugars and to produce acid, hydrogen sulfide $\left(\mathrm{H}_{2} \mathrm{~S}\right)$, and/or gas. Ten milliliters $(10 \mathrm{ml})$ of TSI medium was prepared into each test tube. The test tubes were properly covered and sterilized in an autoclave at $121^{\circ} \mathrm{C}$ for 15 minutes. After sterilization, a sterilized inoculation loop was used to pick an isolated colony and inoculated on TSI agar by firstly stabbed through the center of the medium to the bottom of the tube and then streaked on the surface of the agar slant. A test tube without inoculated organism served as control. The test tubes were incubated for $24 \mathrm{~h}$ at $37^{\circ} \mathrm{C}$ and observed for acid, $\mathrm{H}_{2} \mathrm{~S}$ and gas production. Yellow coloration indicated acid production, $\mathrm{H}_{2} \mathrm{~S}$ production was indicated by black colour while gas production was indicated by bubbles/cracks on the medium. ${ }^{15}$

\section{Motility test}

A drop of bacterial suspension was placed on the center of cover slip, soft paraffin was applied over the corners of the cover slip. A glass slide was gently placed over the cover slip and held upside down. It was in such a manner that bacterial was hanging between the cover slip and glass slide. The bacterial isolate was first examined under the microscope with 10x magnification and later with $40 \mathrm{x}$ magnification. ${ }^{14}$

\section{Oxidase test}

A piece of a filter paper was placed on a clean petri dish; 3 drops of oxidase reagent was added on the filter. Using a piece of sterile wooden stick, the organisms were collected and smear on the filter paper. The appearance of a blue-purple colour within 10 seconds indicates a positive reaction. ${ }^{14}$

\section{Indole test}

The test isolate was inoculated into a bijou bottle containing $3 \mathrm{ml}$ of sterile peptone water. This was incubated for 48 hours at $37^{\circ} \mathrm{C}$. About $0.5 \mathrm{ml}$ of Kovac's reagent was added and shaken gently. Appearance of red colour indicates the presence of indole. ${ }^{14}$

\section{Coagulase test}

A drop of physiological saline was placed on each end of a slide. A colony of the test organism in each of the drop was emulsified to make a thick suspension. A drop of plasma to one of the suspension was gently mixed. Clumping of the organisms within 10 seconds indicated a positive coagulase test. ${ }^{14}$

\section{Methyl red test}

Exactly five millimeters of glucose phosphate broth ( $1 \mathrm{~g}$ glucose, $0.5 \% \mathrm{KH}_{2} \mathrm{PO}_{4}, 0.5 \%$ peptone and $100 \mathrm{~mL}$ distilled water) were dispensed in clean test tubes and sterilized. The tubes were then inoculated with the test organisms and incubated at $37^{\circ} \mathrm{C}$ for $48 \mathrm{~h}$. At the end of incubation, few drops of methyl red solution were added to each test and colour change was observed. A red colour indicates a positive reaction. ${ }^{13}$

\section{Voges-Proskaeur test}

Exactly five millimeter of glucose phosphate broth were dispensed in clean test tubes and sterilized. The tubes were then inoculated with the test organisms and incubated at $37^{\circ} \mathrm{C}$ for $48 \mathrm{~h}$. After incubation, $6 \% \alpha$-naphthol and $6 \%$ Sodium hydroxide were added to about $1 \mathrm{~mL}$ of the broth culture. A strong red coloration formed within $30 \mathrm{~min}$ indicates positive reaction. ${ }^{13}$

\section{Optochin test}

Streptococcus pneumoniae strains are sensitive to the chemical optochin (ethylhydrocupreine hydrochloride). Optochin sensitivity allows for the identification of alpha-hemolytic streptococci such as S. pneumoniae, other alpha-hemolytic Streptococcal species are optochin-resistant. Commercially made Optochin (P) disks $(6 \mathrm{~mm}$, $5 \mu \mathrm{g}$ ) were obtained. Optochin disks are often called "P disks" and are labeled with a capital "P". The tested strain was grown for $24 \mathrm{~h}$ on a blood agar plate at $37^{\circ} \mathrm{C}$ in a candle-jar. A loop was used to remove isolated colony from the overnight culture on the blood agar plate and streaked onto fresh blood agar plate. 'P' disk was placed within the streaked area of the plate and was incubated for $24 \mathrm{~h}$ at $37^{\circ} \mathrm{C}$ in a candle-jar. The growth on the plate near the 'P' disk was observed and the zones of inhibition were measured. A zones of inhibition of $14 \mathrm{~mm}$ or greater indicates sensitivity and allows for identification of pneumococci.

\section{Preparation of media}

All the media used were prepared according to the manufacturer's 
specification and sterilized using autoclave at $121^{\circ} \mathrm{C}$ for 15 minutes The media used were nutrient agar, MacConkey agar, blood agar, chocolate agar for the isolation of pathogens from blood samples and Mueller Hinton (MH) agar for antibiotics susceptibility test.

\section{Antibiotic disc sensitivity testing}

The Kirby-Bauer disc diffusion method of Bauer et al., ${ }^{16}$ and Cheesbrough ${ }^{14}$ were used to determine antibiotic susceptibility on Mueller-Hinton (MH) agar (Oxoid Ltd., England). The bacterial isolates were tested against antibiotic discs (Fondiscs, Nigeria) which comprised of Augmentin-Amoxicillin/Clavulanic Acid $(30 \mu \mathrm{g})$, Ceftriaxone $(30 \mu \mathrm{g})$, Nitrofurantoin $(300 \mu \mathrm{g})$, Gentamicin $(10 \mu \mathrm{g})$, Cotrimoxazole $(25 \mu \mathrm{g})$, Ofloxacin $(5 \mu \mathrm{g})$, Amoxycillin $(25 \mu \mathrm{g})$, Ciprofloxacin $(5 \mu \mathrm{g})$, Tetracycline $(30 \mu \mathrm{g})$, Pefloxacin $(5 \mu \mathrm{g})$, Streptomycin $(10 \mu \mathrm{g})$, chloramphenicol $(30 \mu \mathrm{g})$ and erythromycin $(15 \mu \mathrm{g})$. They were grouped accordingly into Gram stain reaction categories (gram positives and negatives) and tested against corresponding Gram category of bacteria. Briefly, for the KirbyBauer test, bacterial suspension was evenly spread onto MH agar and allowed to dry. Antibiotics discs were then placed on the surface of the agar and incubated at $37^{\circ} \mathrm{C}$ for $24 \mathrm{~h}$. Thereafter, growth inhibition zones were measured with a ruler, and values obtained interpreted as sensitive or resistant according to the Clinical and Laboratory Standards Institute CLSI, ${ }^{11}$ guidelines.

\section{Determination of multiple antibiotic resistance (MAR)} index

Multiple Antibiotic Resistance index is a useful differentiation tool in bacterial source tracking and risks analysis by analyzing resistance profile of bacteria against antibiotics tested. ${ }^{17}$ MAR was calculated as reported by Christopher and Ali, (2013) as follows:

MAR index $=$ Number of antibiotics to which the isolate showed resistance

Number of total antibiotics exposed to the isolate

Results were interpreted according to the criteria of Nandi \& Mandal: ${ }^{18}$

MAR index $\leq 0.2$ was considered low risk, while $\geq 0.2$ indicated a high risk of antibiotic contamination.

\section{Extraction of Plasmid}

Plasmids were extracted following the method described by Zhou et al. ${ }^{19}$ Briefly, cell pellets were obtained from $5 \mathrm{ml}$ of an overnight bacteria broth by centrifugation at $13,000 \mathrm{rpm}$ for $1 \mathrm{~min}$ in a centrifuge (Eppendorf 5418, Germany). Pellets were re-suspended in residual supernatant $(\approx 50 \mu \mathrm{l})$ by vortexing, and $300 \mu \mathrm{l}$ of TENS $(25 \mathrm{mM}$ Tris, $10 \mathrm{mM}$ EDTA, $0.1 \mathrm{~N} \mathrm{NaOH}$ and $0.5 \%$ SDS) added and mixed by inverting tubes about 3-5 times. Subsequently, $150 \mu 1$ of $3 \mathrm{M}$ sodium acetate ( $\mathrm{pH}$ 5.2) was added, vortexed thoroughly, and centrifuged for 5 min to pellet cell debris and chromosomal DNA. Clear supernatant was then carefully transferred into a new $1.5 \mathrm{ml}$ micro centrifuge tube, mixed thoroughly with $900 \mu$ l of ice cold absolute ethanol, and centrifuged for $10 \mathrm{~min}$ to pellet down. Pellets were further washed with $1 \mathrm{ml}$ of cold $70 \%$ ethanol, air dried and re-suspended in $20 \mu 1$ of TE buffer (10mM Tris-CL, pH 7.5; 1 mM EDTA). The integrity of the re-suspended pellets (plasmids) was verified on $1 \%$ agarose gel electrophoresis.

\section{Plasmid curing and re-assessment of antibiotic susceptibility}

Bacteria isolates containing plasmids and those not containing plasmid (in order to nullify false-negative results that might be associated with plasmid extraction protocol) were used for a plasmid curing procedure using acridine orange by following the method described by Akortha \& Filgona ${ }^{20}$ with slight modification. A $5 \mathrm{ml}$ aliquot of overnight suspension cultures of bacteria were sub-cultured into tubes containing $5 \mathrm{ml}$ of nutrient broth supplemented with 0.1 $\mathrm{mg} / \mathrm{ml}$ acridine orange. Tubes were then incubated at $37^{\circ} \mathrm{C}$ for $48 \mathrm{~h}$. Subsequently, these bacterial cultures were then plated out on MuellerHinton agar and used in the re-assessment of antibiotic susceptibility pattern as described above.

\section{Statistical analysis}

The data was subjected to one way analysis of variance (ANOVA) and differences between samples were determined by Duncan's Multiple Range test using SPSS 16.0 version. $P$ values $<0.05$ was regarded as significant and $P$ values $<0.01$ as very significant.

\section{Results}

\section{Anti-HCV positive blood samples cultured}

Out of $121 \mathrm{HCV}$ positive blood sample cultured, exactly 63 showed bacterial growths while 58 positive blood samples did not shown any growth. Of the 63 bacteremic blood samples, 25 blood samples showed mixed bacteria growth as shown in Table 3 . The total number of pure isolates obtained was 148 bacteria as shown in Table 2 .

\section{Isolation and identification of microorganisms associated with blood samples}

Table 1 shows the morphological and biochemical characterization of the isolated Bacteria from both $\mathrm{HCV}$ infected and non-infected blood samples. Microorganisms isolated shown different form of colony which include circular, round, raised, spiral and flat. The shape ranges from short-rod, rod to cocci. Biochemical tests showed that five out of the seven isolated organisms were Gram-negative, while two were Gram-positive. Escherichia coli, S. aureus, P. mirabilis, $P$. aeruginosa, Salmonella sp. were catalase positive, whereas, $S$. pneumoniae and $K$. pneumoniae were catalase negative. E. coli, $P$. mirabilis, $S$. pneumoniae, $P$. aeruginosa were coagulate negative, $K$. pneumoniae and S.aureus were coagulase positive. E. coli, P. mirabilis are indole positive whereas others were negative. P. aeruginosa and $K$. pneumoniae were citrate positive while $E$. coli and S. pneumoniae were negative. Only $P$. aeruginosa and Salmonella sp. were oxidase positive, while all others were negative. Only P. aeruginosa was not utilized the sugars in the TSI agar while others did, Gas production was only by E. coli, but P. mirabilis and Salmonella sp. were $\mathrm{H}_{2} \mathrm{~S}$ positive while others were negative, S. pneumoniae are optochin positive while $S$. aureus negative.

\section{Types and frequency of occurrence of bacterial isolates from the HCV infected blood samples}

A total of seven (7) bacterial species were isolated from the HCV infected blood. These isolates are S. aureus, K. pneumoniae, P. aeruginosa, Escherichia coli, S. pneumoniae, P. mirabilis and Salmonella sp. With $S$. aureus had the highest occurrence of 
$35(23.65 \%)$ followed by E. coli with $31(20.95 \%)$, Salmonella $\mathrm{sp}$. with 23(15.54\%), P. aeruginosa with 20 (13.51\%), K. pneumoniae Table I Morphological and biochemical characterization of isolate with $16(10.81 \%)$, S. pneumoniae $13(8.78)$ and P. mirabilis with 10 $(6.76 \%)$ the least as shown in Table 2.

\begin{tabular}{|c|c|c|c|c|c|c|c|c|c|c|c|c|c|c|c|c|}
\hline \multirow{2}{*}{ Microorganism } & \multirow{2}{*}{ Col } & \multirow{2}{*}{ Gra } & \multirow{2}{*}{ Sha } & \multirow{2}{*}{ Mot } & \multirow{2}{*}{ Cat } & \multirow{2}{*}{ Oxi } & \multirow{2}{*}{ Ind } & \multirow{2}{*}{ MR } & \multirow{2}{*}{ VP } & \multirow{2}{*}{ Coa } & \multirow{2}{*}{ Cit } & \multirow{2}{*}{ Opt } & \multicolumn{4}{|c|}{ TSI } \\
\hline & & & & & & & & & & & & & $\mathbf{s}$ & B & G & $\mathbf{H}_{2} \mathbf{S}$ \\
\hline Staphylococcus aureus & Round & + & Cocci & - & + & - & - & + & - & + & $\mathrm{DE}$ & - & Y & Y & - & - \\
\hline Klebsiella pneumonia & Raised & _ & Rod & _- & _ & _- & - & _ & + & + & + & NA & Y & Y & - & _ \\
\hline Pseudomonas aeruginosa & Flat & - & Rod & + & + & + & - & - & - & - & + & NA & $\mathrm{R}$ & $\mathrm{R}$ & - & - \\
\hline Escherichia & Circular & - & Short & + & + & - & + & + & - & - & - & NA & $Y$ & Y & + & - \\
\hline Coli & & & Rod & & & & & & & & & & & & & \\
\hline Streptococcus pneumonia & Raised & + & Cocci & - & - & - & - & - & + & _ & _ & + & $Y$ & Y & - & _- \\
\hline Proteus mirabilis & Spiral & _ & Rod & + & + & _- & + & + & _ & _ & $\mathrm{DE}$ & NA & $Y$ & Y & - & + \\
\hline Salmonella sp. & Circular & - & Rod & + & + & -- & -- & + & -- & -- & + & NA & $\mathrm{R}$ & Y & - & + \\
\hline
\end{tabular}

Keywords: COL, Colony; GRA, Gram reaction; SHA, Shape; CAT, Catalase; MOT, Motility; COA, Coagulase; LAC, Lactose; OXI, Oxidase; IND, Indole; MR, Methylred;VP,Voges Proskauer; CIT, Citrate; OPT, Optochin;TSI,Triple Sugar Iron; G, Gas; S, Slope; B, Butt; $\mathrm{H}_{2}$ S, Hydrogen Sulphide; R, Red, Y,Yellow; NA, Not Applicable; + , positive, -, negative; $\mathrm{DE}$, Delayed.

Table 2 Types and frequency of occurrence of bacterial isolates from the $\mathrm{HCV}$ infected blood samples

\begin{tabular}{llll}
\hline S/N & Microorganism & Frequency & $\begin{array}{l}\text { Percentage } \\
(\%)\end{array}$ \\
\hline 1 & Staphylococcus aureus & 35 & 23.65 \\
2 & Klebsiella pneumoniae & 16 & 10.81 \\
3 & Salmonella sp. & 23 & 15.54 \\
4 & Pseudomonas aeruginosa & 20 & 13.51 \\
5 & Escherichia coli & 31 & 20.95 \\
6 & Streptococcus pneumoniae & 13 & 8.78 \\
7 & Proteus mirabilis & 10 & 6.76 \\
Total & 7 & 148 & 100 \\
\hline
\end{tabular}

Frequency of occurrence of mixed bacterial pathogens in the samples of HCV infected blood

More than one bacterial species were isolated in 25 of the individuals sampled as shown in Table 3. Staphylococcus aureus/ Escherichia coli has the highest frequency of $11(44 \%)$, followed by Escherichia coli/Salmonella sp. with frequency of 6 (24\%), followed by Salmonella sp./Klebsiella pneumoniae with the frequency of 5 (20) and the least Pseudomonas aeruginosa/Proteus mirabilis with the frequency of $3(12 \%)$.

\section{Percentage antibiotic resistance of gram positive isolates}

The antibiotic resistance pattern of the bacteria isolated from the HCV positive blood samples were conducted. Table 4 showed the percentage resistance pattern of Gram positive isolates, all of them demonstrated high level of resistance to Erythromycin, Cotrimoxazole, Amoxycillin, Ceftriaxone, Pefloxacin and Ofloxacin. Ciprofloxacin showed to be most effective of all the antibiotics used. The antibiotics resistance pattern of the isolates showed the following ranges; Erythromycin (86-91\%), Cotrimoxazole (62-71\%), Amoxycillin (57-69\%), Ceftriaxone (54-66\%), Pefloxacin (37-39\%),
Ofloxacin (23-34\%), Chloramphenicol (8-31\%), Gentamycin (15$17 \%)$, Streptomycin $(0-14 \%)$ and the least percentages of $(0-6)$ were resistant to Ciprofloxacin.

Table 3 Frequency of occurrence of mixed bacterial pathogens in the samples of HCV infected blood

\begin{tabular}{llll}
\hline S/N & Bacterial isolates & Frequency & Percentage (\%) \\
\hline I & $\begin{array}{l}\text { Staphylococcus aureus / } \\
\text { Escherichia coli }\end{array}$ & II & 44 \\
2 & $\begin{array}{l}\text { Pseudomonas aeruginosa / } \\
\text { Proteus mirabilis }\end{array}$ & 3 & 12 \\
3 & $\begin{array}{l}\text { Salmonella sp. / } \\
\text { Klebsiella pneumoniae }\end{array}$ & 5 & 20 \\
4 & $\begin{array}{l}\text { Escherichia coli / } \\
\text { Salmonella sp. }\end{array}$ & 6 & 24 \\
Total & 25 & 100 \\
\hline
\end{tabular}

Percentage antibiotic resistance of gram negative isolates

Table 5 showed the percentage resistance pattern of Gram negative isolates from HCV positive blood samples which showed the following ranges; Amoxicillin (100-100\%), Augmentin (90-100\%), Cotrimoxazole $(81-100 \%)$, Ceftriaxone (74-100\%), Nitrofurantoin (13-36\%), Tetracycline (13-30\%), Gentamycin (6-30\%), Ofloxaxin $(9-10 \%)$, Pefloxacin $(6-9 \%)$ and the least percentages of $(0-5 \%)$ were resistant to Ciprofloxacin.

\section{Multiple antibiotic resistance (MAR) isolates from HCV infected blood according to number and combination of antibiotics}

Table 6 shows the multiple antibiotics resistance of isolates from $\mathrm{HCV}$ positive blood samples with numbers and combination of antibiotics. 
Table 4 Percentage antibiotic resistance of Gram positive isolates (HCV positive)

\begin{tabular}{|c|c|c|c|c|c|c|c|c|c|c|c|}
\hline \multirow{2}{*}{ Bacterial isolates } & \multirow{2}{*}{ No of isolates } & \multicolumn{10}{|c|}{ Percentage resistance to antibiotics (\%) } \\
\hline & & AMX & OFL & STR & CHL & CRO & GEN & PEF & COT & CIP & ERY \\
\hline SA & 35 & 57 & 34 & 14 & 31 & 66 & 17 & 37 & 71 & 6 & 86 \\
\hline SP & 13 & 69 & 23 & 0 & 8 & 54 & 15 & 39 & 62 & 0 & 91 \\
\hline
\end{tabular}

Keywords: SA, Staphylococcus aureus; AMX, Amoxycillin; STR, Streptomycin; COT, Cotrimoxazole; SP, Streptococcus pneumoniae; OFL, Ofloxacin; CHL, Chloramphenicol ;CIP, Ciprofloxacin; CRO, Ceftriaxone; GEN, Gentamycin; PEF, Pefloxacin; ERY, Erythromycin

Table 5 Percentage antibiotic resistance of Gram Negative isolates (HCV positive)

\begin{tabular}{|c|c|c|c|c|c|c|c|c|c|c|c|}
\hline \multirow[b]{2}{*}{ Bacterial isolates } & \multirow[b]{2}{*}{ No of isolates } & \multicolumn{10}{|c|}{ Percentage resistance to antibiotics (\%) } \\
\hline & & AUG & CRO & NIT & GEN & СОT & OFL & $A M X$ & CIP & TET & PEF \\
\hline $\mathrm{KP}$ & 16 & 94 & 88 & 13 & 6 & 81 & 0 & 100 & 0 & 19 & 6 \\
\hline PA & 20 & 90 & 96 & 0 & 10 & 80 & 0 & 100 & 5 & 25 & 0 \\
\hline EC & 31 & 90 & 74 & 36 & 16 & 87 & 10 & 100 & 0 & 30 & 0 \\
\hline PM & 10 & 90 & 100 & 20 & 30 & 100 & 0 & 100 & 0 & 30 & 0 \\
\hline SS & 23 & 100 & 74 & 22 & 22 & 87 & 9 & 100 & 0 & 13 & 9 \\
\hline
\end{tabular}

Keywords: KP, Klebsiella pneumoniae;AUG,Augmentin; CRO, Ceftriaxone; COT, Cotrimoxazole; PA, Pseudomonas aeruginosa; NIT, Nitrofurantoin; GEN, Gentamycin; OFL, Ofloxacin; EC, Escherichia coli;AMX, Amoxycillin; CIP, Ciprofloxacin;TET, Tetracycline; PM, Proteus mirabilis; SS, Salmonella sp.; PEF, Pefloxacin

Table 6 Multiple antibiotic resistance of HCV positive isolates according to number and combination of antibiotics (resistotype)

\begin{tabular}{|c|c|c|c|}
\hline \multirow{2}{*}{ Microorganisms } & \multirow{2}{*}{ No of isolates } & \multicolumn{2}{|c|}{ Antibiotics to which isolates were resistant } \\
\hline & & Number & Combinations \\
\hline \multirow{7}{*}{ S. aureus } & 2 & 4 & ERY, COT, PEF, GEN \\
\hline & 1 & 4 & ERY, COT, PEF, CRO \\
\hline & 5 & 5 & ERY, COT, CRO, CHL,AMX \\
\hline & & & \\
\hline & 6 & 5 & ERY, PEF, CHL, OFL, COT \\
\hline & 4 & 5 & AMX, ERY, CRO, GEN, COT, CHL \\
\hline & 5 & 7 & OFL, CRO, ERY, COT,AMX, STR, PEF \\
\hline \multirow{5}{*}{ S. pneumoniae } & 2 & 4 & PEF, AMX, ERY, COT \\
\hline & 2 & 4 & ERY, PEF,AMX, CRO \\
\hline & & & \\
\hline & 2 & 6 & GEN, OFL, ERY, AMX, COT, CRO \\
\hline & I & 6 & CHL, OFL, AMX, PEF, CRO, COT, ERY \\
\hline \multirow{5}{*}{ K. pneumoniae } & 2 & 4 & AUG, CRO, COT,AMX \\
\hline & 1 & 5 & AUG, CRO, COT,AMX, GEN \\
\hline & 2 & 5 & AUG, COT,AMX, CRO,TET \\
\hline & 3 & 5 & GEN,AMX, CRO, COT,AUG \\
\hline & I & 6 & AMX,TET, COT,AUG, PEF, CRO \\
\hline
\end{tabular}


Table Continued

\begin{tabular}{|c|c|c|c|}
\hline \multirow{2}{*}{ Microorganisms } & \multirow{2}{*}{ No of isolates } & \multicolumn{2}{|c|}{ Antibiotics to which isolates were resistant } \\
\hline & & Number & Combinations \\
\hline \multirow{5}{*}{$P$. aeruginosa } & 8 & 4 & AUG, CRO, COT,AMX \\
\hline & I & 5 & AUG, CRO, COT,AMX,TET \\
\hline & & & \\
\hline & 2 & 5 & AMX,TET,AUG, CRO, COT \\
\hline & 2 & 6 & AMX,AUG, CRO, COT,TET, GEN \\
\hline \multirow{5}{*}{ E. coli } & 8 & 4 & AMX, CRO,AUG, COT, \\
\hline & 6 & 5 & AUG, CRO, COT,AMX, NIT \\
\hline & & & \\
\hline & 2 & 6 & AUG, CRO, COT,AMX,TET, NIT \\
\hline & 3 & 8 & AMX,AUG, GEN, TET, COT, CRO, OFL, NIT \\
\hline \multirow{5}{*}{ P. mirabilis } & 2 & 4 & AMX,AUG, CRO, COT \\
\hline & $\mathrm{I}$ & 5 & AMX,AUG, CRO, COT, NIT \\
\hline & 1 & 5 & AMX,AUG, CRO, COT,TET \\
\hline & $\mathrm{I}$ & 5 & AMX, AUG, CRO, COT, GEN \\
\hline & 2 & 6 & AMX,AUG, CRO, COT,TET, GEN \\
\hline \multirow{5}{*}{ Salmonella sp. } & 5 & 3 & AUG,AMX, COT, CEF \\
\hline & 2 & 3 & ERY, PEF, GEN, TET \\
\hline & & & \\
\hline & 2 & 6 & CHL,AMX,AUG, CRO, OFL \\
\hline & 1 & 8 & AMX, AUG, GEN, TET, COT, CRO, OFL, NIT \\
\hline
\end{tabular}

Keywords:AUG,Augmentin; CRO, Ceftriaxone; COT, Cotrimoxazole; NIT, Nitrofurantoin; GEN, Gentamycin; OFL, Ofloxacin;AMX,Amoxycillin; CIP, Ciprofloxacin; TET, Tetracycline; PEF, Pefloxacin;AMX,Amoxycillin; STR, Streptomycin; CHL, Chloramphenicol; GEN, Gentamycin; ERY, Erythromycin

Multiple antibiotic resistance (MAR) pattern of bacterial isolates from $\mathrm{HCV}$ infected blood

A little more than half (58.11\%) of the total isolates exhibited multiple resistance with the antibiotics they were tested against. The percentage incidence of multiple antibiotic resistance among the isolates include; $S$. aureus with the highest percentage of $65.71 \%$, P. aeruginosa $(65 \%)$, E. coli $(61.29 \%)$, P. mirabilis $(60 \%), S$. pneumoniae $(53.85 \%)$, K. pneumoniae (50\%) and Salmonella sp. with the least percentage of $43.48 \%$ as shown in Table 7 .

Table 7 Multiple antibiotic resistance patterns of bacterial isolates from HCV infected blood

\begin{tabular}{llll}
\hline Organisms & Total number Isolated & Number of isolates with MAR & Percentages of MAR isolates (\%) \\
\hline S. aureus & 35 & 23 & 65.71 \\
S. pneumoniae & 13 & 7 & 53.85 \\
K. pneumoniae & 16 & 8 & 50 \\
P. aeruginosa & 20 & 13 & 65 \\
E. coli & 31 & 19 & 61.29 \\
P. mirabilis & 10 & 6 & 60 \\
Salmonella sp. & 23 & 10 & 43.48 \\
Total & 148 & $86(58.11 \%)$ & \\
\hline
\end{tabular}




\section{Multiple antibiotic resistance (MAR) index}

The resistance of selected isolates towards these antibiotics tested is represented as multiple antibiotics resistance (MAR) index which ranged from 0.6-0.8 (Table 8) (Figure 1) (Table $9 \& 10$ ).

Table 8 Multiple antibiotic resistance (MAR) index

\begin{tabular}{ll}
\hline Microorganisms & MAR \\
\hline S. aureus & 0.7 \\
S. pneumoniae & 0.7 \\
K. pneumoniae & 0.6 \\
P. aeruginosa & 0.6 \\
E. coli & 0.8 \\
P. mirabilis & 0.6 \\
Salmonella sp. & 0.8 \\
\hline
\end{tabular}

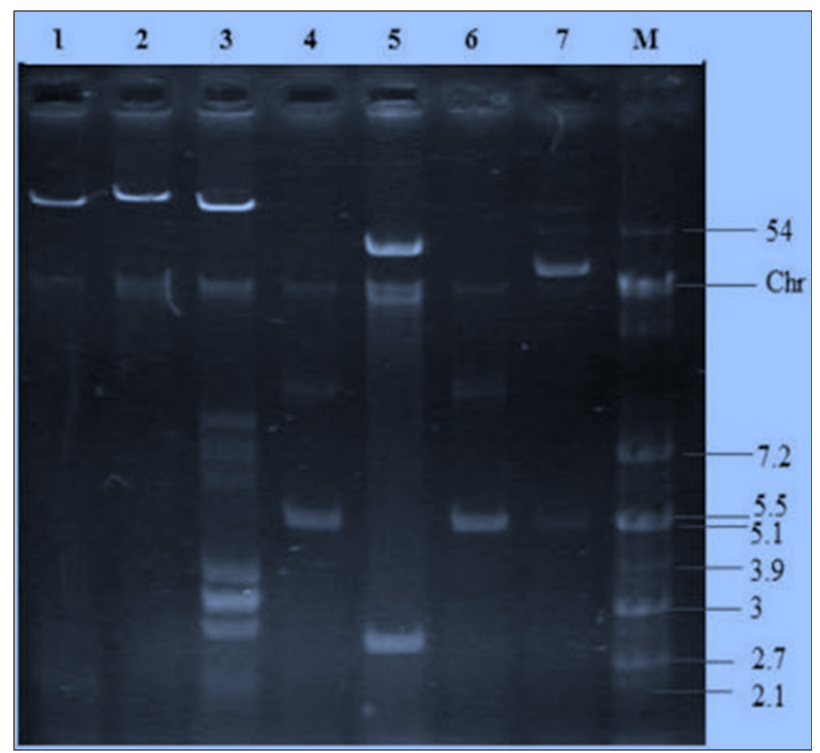

Figure I Plasmid profiles ( I-7) of some multiple antibiotics resistant bacteria isolate.

Keywords: M, Size marker E. coli V5I7; Lanes I, S. aureus, 2, K. pneumoniae, 3, Salmonella sp., 4, P. mirabilis, 5, P. aeruginosa, 6, S. pneumoniae, 7, E. coli.

Table 9 Pre and post sensitivity curing of multiple antibiotics resistant gram positive isolates

\begin{tabular}{|c|c|c|c|}
\hline \multirow{2}{*}{ Antibiotics } & \multirow{2}{*}{$\begin{array}{l}\text { Plasmid } \\
\text { curing }\end{array}$} & \multicolumn{2}{|c|}{ Zones of Inhibition (diameter in $\mathbf{m m}$ ) } \\
\hline & & S. aureus & S. pneumoniae \\
\hline \multirow{2}{*}{ Amoxycillin } & Before & $3.05 \pm 0.04^{b}$ & $0.00 \pm 0.00^{\mathrm{a}}$ \\
\hline & After & $5.13 \pm 0.06^{c}$ & $12.05 \pm 0.02^{\mathrm{d}}$ \\
\hline \multirow{2}{*}{ Ofloxacin } & Before & $12.82 \pm 0.02^{\mathrm{a}}$ & $|2.63 \pm 0.0|^{a}$ \\
\hline & After & $22.27 \pm 0.18^{b}$ & $23.13 \pm 0.01^{\mathrm{c}}$ \\
\hline \multirow{2}{*}{ Streptomycin } & Before & $10.01 \pm 0.0 I^{b}$ & $2.13 \pm 0.03^{\mathrm{a}}$ \\
\hline & After & $19.10 \pm 0.04^{d}$ & $16.20 \pm 0.12^{\mathrm{c}}$ \\
\hline \multirow{2}{*}{ Chloramphenicol } & Before & $5.13 \pm 0.03^{b}$ & $0.00 \pm 0.00^{\mathrm{a}}$ \\
\hline & After & $18.11 \pm 0.10^{\mathrm{d}}$ & $15.07 \pm 0.07^{c}$ \\
\hline \multirow{2}{*}{ Ceftriaxone } & Before & $4.54 \pm 0.02^{\mathrm{a}}$ & $6.28 \pm 0.02^{b}$ \\
\hline & After & $21.98 \pm 0.06^{\mathrm{d}}$ & $21.00 \pm 0.00^{c}$ \\
\hline \multirow{2}{*}{ Gentamicin } & Before & $6.73 \pm 0.03^{\mathrm{a}}$ & $8.37 \pm 0.03^{b}$ \\
\hline & After & $15.10 \pm 0.06^{d}$ & $13.00 \pm 0.06^{c}$ \\
\hline \multirow{2}{*}{ Pefloxacin } & Before & $11.20 \pm 0.12^{b}$ & $9.60 \pm 0.17^{\mathrm{a}}$ \\
\hline & After & $18.14 \pm 0.07^{\mathrm{a}}$ & $16.28 \pm 0.03^{c}$ \\
\hline \multirow{2}{*}{ Ciprofloxacin } & Before & $20.91 \pm 0.01^{c}$ & $13.50 \pm 0.06^{\mathrm{a}}$ \\
\hline & After & $20.91 \pm 0.0 I^{c}$ & $15.23 \pm 0.09^{b}$ \\
\hline \multirow{2}{*}{ Erythromycin } & Before & $5.00 \pm 0.15^{b}$ & $0.33 \pm 0.24^{\mathrm{a}}$ \\
\hline & After & $10.33 \pm 0.28^{d}$ & $6.10 \pm 0.10^{c}$ \\
\hline \multirow{2}{*}{ Cotrimoxazole } & Before & $0.00 \pm 0.00^{\mathrm{a}}$ & $0.00 \pm 0.00^{\mathrm{a}}$ \\
\hline & After & $|3.6| \pm\left. 0.0\right|^{c}$ & $5.35 \pm 0.04^{b}$ \\
\hline
\end{tabular}

Data are presented as Mean $\pm S . E(n=3)$.Values with the same superscript letter(s) along the same column are not significantly different $(P<0.05)$ 
Table 10 Pre and post sensitivity curing of multiple antibiotics resistant gram negative isolates

\begin{tabular}{|c|c|c|c|c|c|c|}
\hline \multirow{2}{*}{ Antibiotics } & \multirow{2}{*}{ Plasmid curing } & \multicolumn{5}{|c|}{ Zone of Inhibition (diameter in $\mathbf{m m}$ ) } \\
\hline & & K. pneumoniae & P. aeruginosa & E. coli & P. mirabilis & Salmonella sp. \\
\hline \multirow{2}{*}{ Augmentin } & Before & $0.00 \pm 0.00^{\mathrm{a}}$ & $0.00 \pm 0.00^{\mathrm{a}}$ & $0.00 \pm 0.00^{\mathrm{a}}$ & $0.00 \pm 0.00^{\mathrm{a}}$ & $0.00 \pm 0.00^{\mathrm{a}}$ \\
\hline & After & $18.73 \pm 0.09^{d}$ & $15.30 \pm 0.15^{c}$ & $20.04 \pm 0.03^{\mathrm{e}}$ & $11.15 \pm 0.08^{\mathrm{a}}$ & $14.29 \pm 0.85^{b}$ \\
\hline \multirow{2}{*}{ Ceftriaxone } & Before & $6.10 \pm 0.06^{b}$ & $9.30 \pm 0.03^{d}$ & $5.13 \pm 0.03^{\mathrm{a}}$ & $9.43 \pm 0.09^{d}$ & $8.20 \pm 0.06^{c}$ \\
\hline & After & $12.00 \pm 0.00^{\mathrm{a}}$ & $15.63 \pm 0.03^{d}$ & $13.90 \pm 0.06^{b}$ & $\mid 6.52 \pm 0.0 \mathrm{I}^{\mathrm{e}}$ & $15.00 \pm 0.00^{c}$ \\
\hline \multirow{2}{*}{ Nitrofurantoin } & Before & $5.2 I \pm 0.06^{c}$ & $4.80 \pm 0.00^{\mathrm{b}}$ & $8.20 \pm 0.00^{d}$ & $5.12 \pm 0.01^{c}$ & $4.22 \pm 0.11^{\mathrm{a}}$ \\
\hline & After & $17.20 \pm 0.06^{c}$ & $16.40 \pm 0.25^{b}$ & $19.07 \pm 0.03^{d}$ & $17.00 \pm 0.06^{c}$ & $15.63 \pm 0.27^{\mathrm{a}}$ \\
\hline \multirow{2}{*}{ Gentamicin } & Before & $8.01 \pm 0.00^{e}$ & $2.93 \pm 0.09^{a}$ & $4.73 \pm 0.09^{b}$ & $6.33 \pm 0.15^{c}$ & $7.57 \pm 0.18^{d}$ \\
\hline & After & $18.05 \pm 0.02^{\mathrm{d}}$ & $15.00 \pm 0.06^{\mathrm{a}}$ & $15.90 \pm 0.00^{\mathrm{b}}$ & $16.00 \pm 0.06^{b}$ & $17.39 \pm 0.26^{c}$ \\
\hline \multirow{2}{*}{ Cotrimoxazole } & Before & $0.00 \pm 0.00^{\mathrm{a}}$ & $0.00 \pm 0.00^{\mathrm{a}}$ & $0.00 \pm 0.00^{\mathrm{a}}$ & $0.00 \pm 0.00^{\mathrm{a}}$ & $0.00 \pm 0.00^{\mathrm{a}}$ \\
\hline & After & $0.00 \pm 0.00^{\mathrm{a}}$ & $4.67 \pm 0.12^{c}$ & $2.00 \pm 0.00^{b}$ & $10.47 \pm 0.18^{d}$ & $12.03 \pm 0.03^{e}$ \\
\hline \multirow{2}{*}{ Ofloxacin } & Before & $11.93 \pm 0.03^{c}$ & $14.77 \pm 0.09^{d}$ & $16.00 \pm 0.06^{\mathrm{e}}$ & $11.40 \pm 0.00^{b}$ & $10.45 \pm 0.18^{\mathrm{a}}$ \\
\hline & After & $20.13 \pm 0.03^{c}$ & $24.20 \pm 0.15^{\mathrm{e}}$ & $17.64 \pm 0.02^{\mathrm{a}}$ & $21.22 \pm 0.11^{\mathrm{d}}$ & $20.4 I \pm 0.0 I^{c}$ \\
\hline \multirow{2}{*}{ Amoxycillin } & Before & $0.00 \pm 0.00^{\mathrm{a}}$ & $3.40 \pm 0.15^{b}$ & $7.11 \pm 0.01^{c}$ & $0.00 \pm 0.00^{\mathrm{a}}$ & $0.00 \pm 0.00^{\mathrm{a}}$ \\
\hline & After & $9.3 I \pm 0.0 I^{a}$ & $13.90 \pm 0.06^{c}$ & $17.80 \pm 0.00^{\mathrm{e}}$ & $|3.1| \pm\left. 0.0\right|^{\mathrm{c}}$ & $15.17 \pm 0.09^{d}$ \\
\hline \multirow{2}{*}{ Ciprofloxacin } & Before & $20.07 \pm 0.03^{a}$ & $22.13 \pm 0.03^{b}$ & $23.32 \pm 0.0 I^{c}$ & $24.61 \pm 0.00^{\mathrm{e}}$ & $24.53 \pm 0.02^{\mathrm{d}}$ \\
\hline & After & $21.20 \pm 0.15^{\mathrm{a}}$ & $23.24 \pm 0.00^{\mathrm{b}}$ & $23.43 \pm 0.03^{b}$ & $24.68 \pm 0.0 \mathrm{I}^{\mathrm{c}}$ & $25.24 \pm 0.07^{d}$ \\
\hline \multirow{2}{*}{ Tetracycline } & Before & $14.11 \pm 0.10^{\mathrm{b}}$ & $0.00 \pm 0.00^{\mathrm{a}}$ & $8.50 \pm 0.15^{d}$ & $10.00 \pm 0.00^{\mathrm{e}}$ & $5.19 \pm 0.09^{c}$ \\
\hline & After & $19.21 \pm 0.06^{d}$ & $12.92 \pm 0.02^{\mathrm{a}}$ & $|5.2| \pm 0.1 I^{\mathrm{c}}$ & $15.46 \pm 0.18^{c}$ & $14.13 \pm 0.09^{b}$ \\
\hline \multirow{2}{*}{ Pefloxacin } & Before & $|8.50 \pm 0.2|^{\mathrm{a}}$ & $20.10 \pm 0.06^{c}$ & $19.10 \pm 0.06^{b}$ & $21.01 \pm 0.00^{d}$ & $23.21 \pm 0.00^{\mathrm{e}}$ \\
\hline & After & $19.70 \pm 0.15^{\mathrm{a}}$ & $22.03 \pm 0.07^{b}$ & $22.07 \pm 0.03^{b}$ & $23.22 \pm 0.00^{c}$ & $23.91 \pm 0.0 I^{d}$ \\
\hline
\end{tabular}

Data are presented as Mean $\pm S . E(n=3)$.Values with the same superscript letter(s) along the same column are not significantly different $(P<0.05)$

\section{Discussion}

Nearly if not all of the bacterial isolates were of medical importance. Both gram negative and gram positive bacteria were obtained but Gram negative bacteria were more frequently involved in the blood samples than Gram positive. Most of the microbial isolates from this study are members of the Enterobacteriaceae family, which is the largest and most heterogenous group of medically significant gramnegative helix-shaped bacteria. They are most frequently isolated in clinical samples. The infections include diarrhoea, dysentery, Salmonellosis, Haemolytic-uremic syndrome (HUS), necrotizing enterocolitis and various nosocomial infections. Pathogenicity of Enterobacteriaceae as a family of gram negative bacteria is associated with the Lipopolysaccharide (LPS) situated in the outer membrane of the bacterial cell wall which is usually responsible for endotoxin production in Gram negative bacteria-a cause of septicemia. Infections from Enterobacteriaceae are regarded as one of the two leading killers of children in developing countries. This goes in agreement with the submission of Frey \& Sherk. ${ }^{21}$

$S$. aureus; a leading cause of bloodstream infections throughout much of the industrialized world ${ }^{22}$ has the highest frequency of $35(23.65 \%)$ and followed by E. coli with 31 (20.95\%), the most common cause of community-acquired bacteremia accounting for approximately $75 \%$ of cases,$^{23}$ the trend of isolates frequency were correlated with that of Michael et al., (1998), also correlated with that of Li et al., (2015), where they focused on bacteria from Hepatitis B. More than one bacterial species were isolated in some blood samples, this is similar with the study carried out by Oladosu et al., ${ }^{24}$ on the evaluation of types of bacterial associated with HIV-1 patients blood.

The antibiotic resistance pattern of the bacteria isolated from the HCV positive blood samples were conducted. All the isolates examined showed resistance to one or more of the ten (10) antibiotics used for the study. Gram positive isolates demonstrated high level of resistance to Erythromycin, Cotrimoxazole, Amoxycillin and Ceftriaxone. Erythromycin was the common antibiotic against which all Gram-positive organisms ( $S$. aureus and $S$. pneumoniae) showed high resistance. In other studies, high level of resistance has been reported with Erythromycin and Ampicillin. ${ }^{25-27}$ Also, Ogunlowo et al., ${ }^{28}$ gave a report of resistance with Erythromycin and Cefuroxime. Streptomycin, Chloramphenicol, Gentamycin was highly sensitive to both organisms. Ciprofloxacin which is a member of the Fluoroquinolones antibiotics was the most effective of all the antibiotics used in the antimicrobial susceptibility testing and this 
agrees with a report from Prajna et al., ${ }^{29}$ on the bacteriologic and clinical efficacy of Ofloxacin and Ciprofloxacin Ophthalmic solutions in the treatment of bacterial isolates of Keratitis, stating that the antibiotics are effective and safe in the treatment of patients with culture positive bacterial keratitis.

Most of the Gram-negative organisms showed resistance to three or more groups of antibiotics. Other researchers also have reported the majority of Gram-negative isolates ( $K$. pneumonia, $P$. aeruginosa, E. coli, P. mirabilis and Salmonella sp.) in their study as multidrug resistant. ${ }^{30}$ Most of the isolates demonstrated resistance to Amoxicillin, Augmentin, Cotrimoxazole, Ceftriaxone. It can be deduced from the result that Amoxicillin and Augmentin were the least effective antibiotics, amoxicillin showing a marked resistance to all the isolates. However, Oluyege et al., ${ }^{31}$ also reported high level resistance of Cotrimoxazone and Ceftriaxone in bacteria isolated from HIV/AIDS. Most of the isolates were highly sensitive to Ciprofloxacin, Pefloxacin, Ofloxacin even to Gentamycin to some extent. Generally, antibiotics showed higher activities against isolates from $\mathrm{HCV}$ negative blood samples. Similar case was reported by Ogunshe et al., ${ }^{32}$ Obinna et al., ${ }^{33}$ and Opere et al. ${ }^{34}$

However, merely all the bacterial species isolated were resistant to Cotrimoxazole, Amoxycillin, Ceftriaxone, Augmentin, Ceftriaxone and Erythromycin but sensitive to Ciprofloxacin, Ofloxacin and Pefloxacin, this is similar to the work of Ernst, ${ }^{35}$ Mahan \& EscottStump $^{36}$ and USDHHS. ${ }^{37}$ The incidence of antibiotic resistance to drugs by microorganisms is explained in their ability to exist even in the presence of the antibiotics having devised mechanisms to survive the effect of the antibiotics due to their genetic flexibility. In this study, the isolated organisms were resistant to most of the commonly used antibiotics. Drug resistances of bacteria to antibiotics have been attributed to the misuse (of antibiotics) as well as the possession of drug resistance plasmids. ${ }^{38}$

Multiple antibiotic resistance (MAR) isolates from HCV infected blood according to their number and combination of antibiotics they were resistant against, showed a combination range from 4-8 resistotype with MAR index which also ranged from $0.4-0.8$. These values were higher than 0.2 suggesting that they might have originated from a high risk source of contamination where antibiotics are often used. ${ }^{39}$ MAR pattern of bacterial isolates from HCV infected blood, where a little more than half $(58.11 \%)$ of the total isolates exhibited multiple resistance with the antibiotics they were tested against, multiple drug resistances of bacteria to antibiotics might be due to misuse and overuse of antibiotics as well as the possession of drug resistance plasmids. ${ }^{38}$

Higher value of multiple antibiotics resistance (MAR) index of isolates ranged from 0.6-0.8 might have been accumulated in several ecological niches because of the widespread use of commercial antibiotics in hospital, agriculture and livestock. Multiple antibiotic resistances (MARs) in bacteria may be commonly associated with the presence of plasmids. The plasmid analysis shows that the multiple resistant bacteria isolates harbor one or more plasmid with different molecular weights. This finding implicates plasmids as the source of resistance genes. Uma et al., ${ }^{40}$ Hudson et al. ${ }^{41}$ and Gohar et al., ${ }^{42}$ also reported that genes for multidrug resistance might be located on plasmid DNA or chromosomal DNA. The susceptibility pattern of antibiotics re-assessment shows that plasmid curing converted all the multiple antibiotics resistance isolates (MAR) which were initially resistant to the conventional antibiotics to susceptible form thereby indicating that, the resistance was plasmid mediated.

\section{Conclusion}

This study thus provides information regarding the types, antibiotic resistance patterns and plasmid profile of resistance bacteria isolated from HCV blood samples. In which the S. aureus is the most frequently encountered bacterial species in the blood of $\mathrm{HCV}$ positive individuals in the community studied while the least encountered pathogen was Proteus mirabilis. All the bacterial species isolated are resistant to Ceftriaxone, Cotrimoxazole, Amoxycillin, Augmentin and Erythromycin but sensitive to Fluoroquinolones especially Ciprofloxacin. Such data is important in the selection of empirical antimicrobial treatment of HCV secondary infection cases; in showing a path for clinical research and as an aid in educating and spreading awareness among medical personnel. This also draws our attention toward emerging trends of antibiotic resistance in pathogenic bacteria. However, as this was a single center study of limited duration, the results may not be generalized for guiding empirical therapy of $\mathrm{HCV}$ secondary infection in the area. It is highly recommended that more studies, involving patients from multiple medical centers are done to throw more light on the epidemiology of infectious diseases, and the resistance patterns of common pathogens; to make practicing physicians aware of the magnitude of an existing problem of antibacterial resistance, so that they join hands in fighting this deadly threat by rational prescription of drugs.

\section{Acknowledgments}

None.

\section{Conflicts of interest}

Authors declare that there is no conflict of interest.

\section{References}

1. Falase AO, Akinkugbe OO. A Compendium of Clinical Medicine. Ibadan Spectrum Books Ltd.; 2003.

2. Ryan IKJ, Ray CG. Sherris Medical Microbiology (4th ed.). McGraw Hill; 2004. 362-368 p.

3. U.S. 2014 Surveillance Data for Viral Hepatitis, Statistics \& Surveillance Division of Viral Hepatitis. CDC; 2016.

4. Maheshwari A, Thuluvath PJ. Management of acute hepatitis C. Clin Liver Dis. 2010;14(1):169-176.

5. Hepatitis C Fact sheet $N^{\circ} 164$. World Health Organization; 2015.

6. Viral Hepatitis: A through E and Beyond. National Institute of Diabetes and Digestive and Kidney Diseases; 2016.

7. Houghton M. Hepatitis C viruses. In: Fields BN, Knipe DM, Howley PM, eds. Fields Virology, $3^{\text {rd }}$ ed. Philadelphia, Lippincott: Raven; 1996. $1035-1058 \mathrm{p}$.

8. Lemon SM, Brown EA. Hepatitis C virus. In: Mandell GL, Bennett JE, Dolin R, eds. Principle and Practice of Infectious Disease. New York, Churchill Livingstone; 1995. 1474-1486 p.

9. Walker CM. Hepatitis C virus. In: Ahmed R, Chen I, eds. Persistent Viral Infections. Chichester: Wiley; 1999. 93-115 p. 
10. Foy E, Kui L, Chunfu W, et al. Regulation of interferon regulatory factor-3 by the hepatitis C virus serine protease. Science. 2003;300(5622):1145 1148 .

11. Perfomance standards for antimicrobial susceptibility testing; Approved Standard-26th Edition. CLSI supplement M100S. Wayne, PA: Clinical and Laboratory Standards Institute; 2016. 256 p.

12. Barraquio VL, Djoko K, Elegado FB. Phenotypic and Genotypic Characterization of Probiotic Bacteria Isolated from Probiotic Dairy Products in the Philippines. Philippine Journal of Science. 2008;137(1):7783.

13. Olutiola PO, Famurewa O, Sonntag HG. An introduction to General Microbiology: A practical Approach. 2nd ed. Heldelberg, Nigeria; 2000. 51-68, 71-131 p.

14. Cheesbrough M. District Laboratory Practice in Tropical Countries. 2nd ed. United Kingdom: Cambridge University Press; 2006. 143 p.

15. Fawole MO, Oso BA. Laboratory Manual of Microbiology. Ibadan, Nigeria: Spectrum Books Limited; 2001. 127 p.

16. Bauer A, Kirby W, Sherris JC, et al. Antibiotic susceptibility testing by standardized single disk method. Am J Clin Pathol. 1966;45(4):493-496.

17. Poonia S, Singh TS, Tsering DC. Antibiotic Susceptibility Profile of Bacteria Isolated from Natural Sources of Water from Rural Areas of East Sikkim. Indian Journal of Community Medicine 2014;39(3):156-160.

18. Nandi S, Mandal S. Bacteriological Profiling of Commercially available Eye Cosmetics and their Antibiotic Susceptibility Pattern. Transl Biomed. 2016;7:3.

19. Zhou C, Yujun Y, Jong AY. Mini-prep in ten minutes. Bio Techniques. 1990;8(2):172-173.

20. Akortha EE, Filgona J. Transfer of gentamicin resistance genes among enterobacteriaceae isolated from the outpatients with urinary tract infections attending 3hospitals in Mubi, Adamawa State. Scientific Research and Essay. 2009;4(8):745-752.

21. Frey R, Sherk S. Gale Encyclopaedia of Children's Health: Infancy through Adolescence. Detroit, MI: Thomson Gale. 2006;20(4):39-41.

22. Rasmussen RV, Fowler VG, Skov R et al. Future challenges and treatment of Staphylococcus aureus bacteremia with emphasis on MRSA. Future Microbiology. 2011;6(1):43-56.

23. Luzzaro F, Viganò EF, Fossati D, et al. Prevalence and drug susceptibility of pathogens causing bloodstream infections in northern Italy: a two-year study in 16 hospitals. Eur J Clin Microbiol Infect Dis. 2002;21(12):849855.

24. Oladosu TO, Adebolu TT, Oladunmoye MK. Evaluation of the Types of Bacteria in the Blood of HIV-1 Patients Attending ART Clinic at the FMC Owo, Nigeria and their Antibiogram Profile. HIV Curr Res. 2016;1(1):103.

25. Arora U, Devi P. Bacterial profile of blood stream infections and antibiotic resistance pattern of isolates. $J$ K Sci. 2007;9(4):186-190.

26. Guha DK, Jaspal D, Das K, et al. Outcome of neonatal septicemia: A clinical and bacteriological profile. Indian Pediatr. 1978;15(5):423-427.
27. Karki BM, Parija SC. Analysis of blood culture isolates from hospitalized neonates in Nepal. Southeast Asian J Trop Med Public Health. 1999;30(3):546-548.

28. Ogunlowo OP, Arimah BD, Olajubutu JJ, et al. Isolation and Antibiotic Susceptibility Pattern of Bacteria Associated with Blood Stream Infections. International Blood Research \& Reviews. 2014;2(2):69-81.

29. Prajna NV, George C, Srinivasan M, et al. Bacteriologic and Clinica Efficacy of Ofloxacin $0.3 \%$ Versus Ciprofloxacin 0.3\% Opthalmic Solutions in the Treatment of Patients with Culture-positive Bacterial Keratitis. Cornea. 2001;20(2):175-178.

30. Roy A, Maiti PK, Adhya S, et al. Neonatal candidemia. Indian J Pediatr. 1993;60(6):799-801.

31. Oluyege AO, Ojo-Bola O, Olagbemi AA. Prevalence and antibiotic resistance pattern of blood culture isolates from human immune-deffiency virus (HIV) patients on highly active anti-retroviral therapy (HAAR) in Nigeria. African Journal of Microbiology Research. 2015;9(13):909-914.

32. Ogunshe A, Niemogha M, Azum G, et al. Microbiological evaluation of antibiotic resistance in bacterial flora from skin wounds. Journal of Pharmaceutical and Biomedical Sciences. 2012;22(6):1-7.

33. Obinna E, Leonard A, Faustina E, et al. Antibiotics Susceptibility Pattern and Plasmid Profile of Bacteria Isolated from Public Motorcycle Helmets. American Journal of Microbiological Research. 2016;4(4):126-131.

34. Opere BO, Ojo JO, Omonigbehin E, et al. Antibiotic susceptibility and plasmid profile analysis of pathogenic bacteria isolated from environmental surfaces in public toilets. Transnational Journal of Science and Technology. 2003;3(2):22-30.

35. Ernst E. Regulation of complementary and alternative medicine. Focus on Alternative and Complementary Therapies; 2005.

36. Mahan LK, Escott-Stump S. Krause's food \& Nutrition therapy. Saunders; 2007.

37. Opportunistic infections and their relationship to HIV/AIDS. United States Department of Health and Human Services; 2010.

38. DubMandal M. Experiments on exploration of environmental bacteria degrading a pesticide used in agriculture. Thesis, University of Jadavpur; 2005.

39. Hemen JT, Johnson JT, Ambo EE, et al. Multi-Antibiotic Resistance of Some Gram Negative Bacterial Isolates from Poultry Litters of Selected Farms in Benue State. IJST. 2012;2:543-547.

40. Uma B, Prabhakar K, Rajendran S, et al. Antibiotic sensitivity and plasmid profiles of Escherichia coli isolated from pediatric diarrhea. J Glob Infect Dis. 2009;1(2):107-110.

41. Hudson C, Bent Z, Meagher R. et al. Resistance Determinants and Mobile Genetic Elements of an NDM-1-Encoding Klebsiella pneumoniae Strain. PLoS One. 2014;9(6):e99209.

42. Gohar M, Sheikh AA, Anjum AA, et al. Plasmid profiling and curing of multidrug resistant Escherichia coli recovered from retail chicken meat. Journal of Animal and Plant Sciences. 2015;25(4):984-988. 